\title{
PERAN TRAIT MINDFULNESS TERHADAP KESEJAHTERAAN PSIKOLOGIS PADA LANSIA
}

\author{
Ayu Suci Purnamaning Dyah ${ }^{1}$, \\ Endang Fourianalistyawati ${ }^{2}$ \\ Fakultas Psikologi \\ Universitas YARSI \\ Jl. Letjen. Suprapto, Cempaka Putih \\ Jakarta Pusat 10510, Indonesia \\ Ie-mail: ayayusuci@gmail.com \\ ${ }^{2}$ e-mail: endangfouriana@gmail.com
}

\begin{abstract}
As individuals enter the elderly stage of development, they undergo many physical, social, spiritual, and psychological changes. Older adults who are not ready for the certain changes may be more susceptible to stress. Stressful conditions may reduce psychological well-being in the elderly. To deal with such issues, older adults need to have the ability to be aware of present experience, or is also called the trait mindfulness. This study attempted to see if the trait mindfulness has a significant role in psychological well-being. The sample of this research was retired older adults living in Jakarta, Bogor, Depok, Tangerang, and Bekasi $(n=120)$. This study used an adapted scale of the Five Facet of Mindfulness Questionnaire (FFMQ) to measure trait mindfulness and an adapted version of the Psychological WellBeing Scale to measure psychological well-being. Regression results indicate that four of the five dimensions of trait mindfulness have significant roles on some dimensions psychological well-being. Those dimensions of trait mindfulness are acting with awareness, describing, non reactivity, and non-judging. Observing is found not to have any significant role in psychological well-being.
\end{abstract}

Keywords: mindfulness; psychological well-being; older adults; elderly

\begin{abstract}
Abstrak - Memasuki masa lansia, individu mengalami banyak perubahan pada kondisi fisik, sosial, spiritual dan psikologisnya. Lansia yang tidak siap dengan perubahan tersebut akan rentan terhadap stres. Kondisi yang demikian dapat menurunkan kesejahteraan psikologis (psychological well-being) pada lansia. Untuk menangani permasalahan tersebut, lansia perlu mengembangkan sifat mindfulness (kemampuan untuk berfokus pada apa yang terjadi saat ini) didalam dirinya. Penelitian ini bertujuan untuk melihat apakah trait mindfulness berperan secara signifikan terhadap kesejahteraan psikologis pada lansia. Sampel penelitian ialah orang-orang yang sudah tidak bekerja dan berdomisili di wilayah Jakarta, Bogor, Depok, Tangerang, dan Bekasi $(\mathrm{n}=120)$. Penelitian ini menggunakan adaptasi skala Five Facet Mindfulness Questionnaire untuk mengukur trait mindfulness dan Scale of Psychological Well Being untuk mengukur kesejahteraan psikologis. Hasil analisis regresi ganda menunjukkan empat dari lima dimensi trait mindfulness berperan signifikan terhadap beberapa dimensi kesejahteraan psikologis.
\end{abstract}


Dimensi-dimensi dari trait mindfulness tersebut yaitu acting with awareness, describing, non-reactivity, dan non-judging. Sementara itu, dimensi lainnya yang tidak berperan adalah observing.

Kata Kunci: mindfulness; kesejahteraan psikologis; lansia

\section{PENDAHULUAN}

Memasuki masa tua dengan sejahtera menjadi dambaan bagi semua individu yang memasuki fase lansia. Menjadi tua merupakan bagian dari rentang kehidupan individu, sehingga kesejahteraan juga menjadi impian bagi setiap lansia. Lansia adalah individu yang telah memasuki usia 60 tahun (Hurlock, 2004). Memasuki masa lansia yang bahagia diidentifikasi dengan kesiapan untuk menerima segala perubahan dalam aspek-aspek kehidupan (Indriana, Destiningrum, \& Kristiana, 2011). Ketidaksiapan lansia dalam menghadapi perubahan tersebut dapat mengakibatkan lansia menjadi sangat rentan terhadap stres dan berakhir dengan rasa putus asa. Syukra (2012) menunjukkan bahwa penyebab depresi yang dialami oleh lansia adalah kekosongan hidup, perasaan bosan dengan hidupnya, dan memiliki rasa takut bahwa sesuatu yang buruk akan terjadi pada dirinya.

Penemuan Syukra (2012) sesuai dengan fenomena sangkar kosong (empty nest) yang biasanya dialami oleh lansia, yaitu krisis pada diri sendiri yang disebabkan oleh rasa kehilangan anak-anaknya yang telah hidup mandiri, memasuki masa pensiun, menopause, serta kematian pasangan ( $\mathrm{Lu}, 2010)$. Beberapa konflik utama yang dialami oleh lansia adalah pelepasan kedudukan dan otoritasnya, serta penilaian terhadap kemampuan, keberhasilan, dan kepuasan yang diperoleh sebelumnya (post power syndrome). Hal tersebut dapat berdampak pada penurunan kondisi fisik dan psikologis lansia (Hawari, 2007).

Konflik utama sebagaimana digambarkan dalam krisis sarang kosong akan mulai dirasakan apabila lansia telah memasuki usia pensiun. Menurut Hurlock (2008), pensiun adalah suatu kondisi di mana seseorang berhenti dari suatu pekerjaan yang ditekuninya, yang berarti berhentinya seseorang dalam mencari nafkah untuk keluarganya. Selain untuk memenuhi kebutuhan materi, bekerja juga dapat memenuhi kebutuhan psikologis seseorang. Secara psikologis, bekerja membuat seseorang memiliki rasa identitas, status, dan juga fungsi sosial (Triratnasari, 2009). Pensiun dipandang sebagai sesuatu yang mengurangi kegiatan rutin, keterlibatan dalam aktivitas sosial individu, bahkan dapat mengancam kesejahteraan psikologis (Newman, dalam Nurhidayah \& Agustini, 2012).

Kesejahteraan psikologis (psychological well-being) menurut Ryff dan Keyes (1995) adalah 
pencapaian penuh dari potensi psikologis seseorang dan suatu keadaan ketika individu dapat menerima kekuatan dan kelemahan diri apa adanya, memiliki tujuan hidup, mengembangkan relasi positif, menjadi pribadi yang mandiri, mampu mengendalikan lingkungan dan terus bertumbuh secara personal. Newman (dalam Nurhidayah \& Agustini, 2012) menyatakan bahwa kesejahteraan psikologis juga bergantung pada kemampuan untuk mengatur atau terus terlibat dalam peran dan kegiatan yang berharga.

Terdapat banyak cara untuk meningkatkan kesejahteraan psikologis, yaitu dengan memberikan dukungan sosial (Destiningrum, 2014), terapi musik klasik (Jasmarizal, Sastra \& Yunita, 2011), psikoterapi kelompok lansia (Zulfiana, 2014), senam lansia (Pratiwi, 2013) dan terapi mindfulness (Kinasih \& Sukma, 2010). Mindfulness adalah kesadaran yang muncul akibat dari pemberian perhatian pada sebuah pengalaman saat ini secara sengaja dan tanpa penilaian (Kabat-Zinn, 2003). Trait mindfulness merupakan sifat perhatian dan kesadaran penuh yang bersifat stabil dan konsisten dalam diri yang mendorong individu untuk terus bertindak.

Pada penelitian lain yang dilakukan oleh Teasdale dkk. (2002), terapi mindfulness terbukti secara signifikan mengurangi tingkat kambuhnya depresi pada kelompok eksperimen dibandingkan dengan kelompok kontrol yang tidak diberikan terapi mindfulness. Penelitian tersebut juga menyatakan bahwa karakteristik populasi lansia sangat cocok untuk menjadi sasaran intervensi berbasis mindfulness. Kesadaran tersebut berfokus pada hubungan antara pikiran dan tubuh, sehingga hal tersebut berkaitan dengan lansia yang mengalami masalah kesehatan fisik dan psikologis (Smith, 2004).

Lansia juga merupakan kelompok yang harus diperhatikan karena jumlahnya yang cukup banyak dan akan terus meningkat sepanjang tahun. Berdasarkan data Susenas (Survei Sosial Ekonomi Nasional) tahun 2014, jumlah lansia di Indonesia mencapai 20,24 juta jiwa, setara dengan $8.03 \%$ dari seluruh penduduk Indonesia di tahun 2014. Selanjutnya, jumlah lansia juga diperkirakan akan mencapai 29 juta atau 11\% dari total populasi pada tahun 2020 (Mustari, Rachmawati, \& Nugroho, 2015).

Berdasarkan data Susenas pada tahun 2014, lansia yang tinggal di desa berjumlah lebih banyak daripada lansia yang tinggal di kota. Berdasarkan data yang didapatkan, terdapat $47.48 \%$ lansia yang masih bekerja untuk memenuhi kebutuhan hidupnya. Jumlah lansia yang bekerja di daerah perdesaan lebih banyak dibandingkan lansia yang tinggal di perkotaan. Padahal, lansia yang berusia di atas 70 tahun (lansia akhir) di perdesaan memiliki proporsi yang lebih banyak dibandingkan usia lansia di perkotaan yang berkisar 60-70 tahun (lansia awal). Lansia di perkotaan juga memiliki pendidikan yang lebih baik dibandingkan lansia di perdesaan, sehingga lansia di perkotaan mayoritas memiliki kemampuan membaca dan menulis. Pada daerah perkotaan, 
pelayanan kesehatan untuk lansia juga dinilai lebih baik daripada di desa. Oleh karena itu, lansia di kota seharusnya memiliki kesejahteraan yang lebih tinggi dibanding lansia di desa. Walaupun demikian, lansia yang tinggal di perkotaan memiliki keluhan kesehatan $2.03 \%$ lebih tinggi dibanding lansia yang ditinggal perdesaan. Bahkan, angka lansia yang menjadi korban kejahatan di perkotaan lebih tinggi daripada yang tinggal di pedesaan (Mustari dkk., 2015).

Berdasarkan penjelasan diatas, peningkatan harapan hidup lansia di satu pihak menjadi indikator kemajuan suatu bangsa, tetapi di pihak lain akan menimbulkan banyak masalah terutama masalah kesehatan dan kerawanan sosial akibat banyaknya lansia yang tidak sejahtera dalam menjalani hidupnya (Hawari, 2007).

Lansia yang tidak sejahtera secara psikologis cenderung lebih banyak memiliki keluhan gangguan penyakit (Khotimah, 2011). Hal tersebut akan berdampak pada meningkatnya biaya kesehatan yang dikeluarkan oleh negara untuk menangani biaya kesehatan lansia (Ambardini, 2009). Keluarga yang tinggal bersama lansia dengan keluhan penyakit juga akan merasa terganggu. Mereka harus membayar seseoang untuk mengasuh lansia yang sakit, atau bahkan mengorbankan salah satu anggota keluarga lainnya untuk tidak bekerja demi mengurus lansia di rumah (Gumelar, 2014). Apabila lansia sejahtera secara psikologis, hal ini akan meringankan keluarga dalam mengurus lansia. Kemudian dengan memperhatikan kesejahteraan psikologis lansia juga merupakan salah satu bentuk bakti seorang anak terhadap orangtuanya. Setiap orang akan memasuki masa tua, sehingga perhatian terhadap kesejahteraannya menjadi esensial. Oleh karena itu, kesejahteraan psikologis pada lansia merupakan hal yang penting untuk diteliti.

Penelitian mengenai trait mindfulness di luar negeri sudah mulai banyak, sedangkan di Indonesia masih sangat sedikit terutama untuk subjek lansia. Sementara, keadaan lansia di Indonesia juga perlu diperhatikan kesejahteraan psikologisnya karena mengingat jumlah lansia di Indonesia yang cukup banyak. Oleh karena itu peneliti memandang bahwa perlu untuk dilakukan penelitian terkait trait mindfulness dan kesejahteraan psikologis pada lansia. Pada penelitian ini, peneliti memilih lansia yang berdomisili di wilayah Jabodetabek (Jakarta, Bogor, Depok, Tangerang dan Bekasi) untuk mewakili gambaran lansia di perkotaan.

\section{Kesejahteraan Psikologis}

Kesejahteraan psikologis adalah suatu keadaan ketika individu memperoleh pencapaian penuh dari potensi psikologisnya, menerima kekuatan dan kelemahan diri apa adanya, memiliki tujuan hidup, mengembangkan relasi yang positif dengan orang lain, menjadi pribadi yang mandiri, mampu mengendalikan lingkungan, dan terus bertumbuh secara personal (Ryff \& Keyes, 1995).

Menurut Ryff (1989), kesejahteraan psikologis memiliki enam dimensi. Pertama, 
penerimaan diri. Individu dapat dikatakan memiliki taraf kesejahteraan psikologis dalam dimensi penerimaan diri apabila dapat mengakui dan menerima berbagai aspek dirinya, memiliki sikap positif terhadap diri sendiri dan merasa positif terhadap kehidupan yang dijalani saat ini. Dimensi kedua adalah hubungan positif dengan orang lain, yaitu adanya kemampuan membina hubungan interpersonal yang hangat dan saling percaya, saling mengembangkan pribadi satu dengan yang lain, kemampuan untuk mencintai, berempati, memiliki afeksi terhadap orang lain, serta mampu menjalin persahabatan yang mendalam.

Dimensi ketiga adalah otonomi. Individu yang otonom memiliki pusat pengendalian internal dalam bertindak. Sebaliknya, orang yang tidak otonom adalah orang yang sangat peduli dengan harapan dan evaluasi orang lain terhadap dirinya, menggantungkan diri pada penilaian orang lain dalam mengambil keputusan, serta mudah dipengaruhi tekanan sosial dalam bertingkah laku dan berpikir. Dimensi keempat adalah penguasaan terhadap lingkungan. Individu yang mampu menguasai lingkungannya adalah individu yang memiliki penguasaan dan kompetensi dalam mengatur lingkungannya, dapat mengendalikan situasi eksternal yang kompleks, dapat menggunakan kesempatan di lingkungan secara efektif, serta mampu memilih atau menciptakan lingkungan yang sesuai dengan kebutuhan dan nilai dirinya.

Dimensi kelima adalah tujuan hidup. Individu yang memiliki tujuan dan arah dalam hidup akan merasa bahwa kehidupan di masa lalu dan masa sekarang memiliki makna, memiliki keyakinan yang memberikan tujuan dalam hidup. Sebaliknya, orang yang dikatakan tidak memiliki tujuan hidup ditandai dengan kurang memahami makna hidup, tidak dapat melihat tujuan dari kehidupan di masa lampau, tidak memiliki keyakinan yang dapat memberikan makna dalam hidup. Dimensi keenam adalah perkembangan pribadi yang ditandai dengan adanya keinginan untuk terus berkembang, terbuka terhadap pengalaman yang baru, memiliki keinginan untuk merealisasikan potensinya, serta dapat melihat kemajuan dalam diri dan perilakunya dari waktu ke waktu.

\section{Trait Mindfulness}

Kabat-Zinn (2003) mendefinisikan trait mindfulness sebagai kesadaran yang muncul akibat pemberian perhatian terhadap sebuah pengalaman saat ini secara sengaja dan tanpa penilaian. Trait mindfulness dapat membuat seseorang mampu merespons dengan penerimaan terhadap pengalaman yang dialami sehari-hari. Trait mindfulness merupakan keadaan penuh perhatian dan sadar terhadap apa yang terjadi pada saat ini.

Trait mindfulness menurut Baer, Smith, Hopkins, Krietemeyer, dan Toney (2006) memiliki lima dimensi. Pertama, bertindak dengan kesadaran (acting with awareness), yaitu perilaku secara sadar yang dilakukan di sini dan saat ini. Kedua, kemampuan mengobservasi (observing), yaitu 
kemampuan memperhatikan pengalaman internal dan eksternal seperti sensasi, kognisi, emosi, suara, aroma dan pengamatan. Ketiga, kemampuan mendeskripsikan (describing), yaitu mengacu pada pengalaman internal yang diungkapkan dengan kata-kata. Keempat, sikap non-reaktif terhadap pengalaman (nonreactivity to inner experience), yaitu adanya keselarasan antara pikiran dan perasaan. Kelima, sikap tanpa penilaian terhadap pengalaman (nonjudging of inner experience), yaitu mengacu pada sikap nonevaluative terhadap pikiran dan perasaan.

\section{METODE}

\section{Partisipan}

Sampel dalam penelitian ini berjumlah 120 lansia (61.6\% perempuan), berusia 60 tahun ke atas yang sudah tidak bekerja dan berdomisili di wilayah Jakarta, Bogor, Depok, Tangerang, dan Bekasi. Penelitian ini menggunakan teknik pengambilan sampel incidental sampling.

\section{Desain}

Desain penelitian ini adalah penelitian asosiatif, di mana peneliti ingin mengetahui hubungan antara trait mindfulness dan kesejahteraan psikologis pada lansia.

\section{Prosedur}

Pengumpulan data dalam penelitian ini menggunakan alat ukur berupa skala mindfulness yaitu Five Facet Mindfulness Questionnaire (FFMQ) yang disusun oleh Baer dkk. (2006). Skala ini terdiri dari 39 butir dengan menggunakan jawaban skala Likert yang terdiri dari lima pilihan jawaban (tidak pernah, jarang, kadang-kadang, sering, dan selalu).

Skala FFMQ menggunakan pengukuran berdasarkan lima dimensi utama mindfulness yaitu acting with awareness, observing, describing, nonjudging of inner experience dan nonreactivity to inner experience. Dalam penelitian ini, dimensi-dimensi FFMQ memiliki koefisien Cronbach's Alpha yang berkisar antara .663 - .747 dan terdapat satu butir yang tidak valid karena memiliki koefisien validitas <.2, yaitu butir nomor 17 pada dimensi nonjudging of inner experience.

Pengukuran kesejahteraan psikologis menggunakan kuesioner Scale of Psychological Well Being (SPWB) dengan menggunakan jawaban skala Likert yang terdiri dari rentang angka satu (sangat tidak setuju) sampai enam (sangat setuju). Alat ukur ini telah diadaptasi oleh Listiyandini dan Brebahama (2015). Hasil yang didapat adalah nilai reliabilitas Cronbach's Alpha yang berkisar di antara .660 sampai dengan .727. 


\section{Teknik Analisis}

Penelitian ini menggunakan teknik analisis regresi ganda dengan metode enter. Selain itu, juga dilakukan uji beda terhadap beberapa data penelitian sebagai analisis data tambahan.

\section{ANALISIS DAN HASIL}

Hasil uji regresi ganda menunjukkan bahwa, kelima dimensi pada trait mindfulness dapat menjelaskan $15.6 \%$ varians dari dimensi penerimaan diri pada kesejahteraan psikologis $(F=4.225$, $p=.001)$.

Selanjutnya, dilakukan analisis regresi untuk mengetahui hubungan trait mindfulness dengan masing-masing dimensi pada kesejahteraan psikologis lansia. Hasil penelitian ini menemukan bahwa kelima dimensi pada trait mindfulness dapat menjelaskan $13.7 \%$ varians dari dimensi hubungan positif dengan orang lain pada kesejahteraan psikologis $(F=3.618, p=.004)$.

Dalam kaitannya dengan dimensi otonomi pada konstruk kesejahteraan psikologis lansia, kelima dimensi pada trait mindfulness dapat menjelaskan $39.7 \%$ varians dari dimensi otonomi pada kesejahteraan psikologis $(F=4.266, p=.001)$.

Trait mindfulness secara keseluruhan diketahui tidak memiliki kontribusi yang signifikan pada dimensi penguasaan lingkungan $(F=2.123, p=.068)$, tujuan hidup $(F=2.217, p=.057)$ dan pertumbuhan pribadi $(F=2.261, p=.053)$.

Tabel 1.

Hasil Uji Regresi Ganda

\begin{tabular}{llcccccc}
\hline & & $\begin{array}{l}\text { Penerimaan } \\
\text { Pribadi }\end{array}$ & $\begin{array}{l}\text { Hubungan } \\
\text { Positif }\end{array}$ & Otonomi & $\begin{array}{c}\text { Penguasaan } \\
\text { Lingkungan }\end{array}$ & $\begin{array}{l}\text { Tujuan } \\
\text { Hidup }\end{array}$ & $\begin{array}{l}\text { Pertumbuhan } \\
\text { Pribadi }\end{array}$ \\
\hline Acting with & $\mathrm{B}$ & .079 & .229 & .072 & .098 & .119 & .131 \\
Awareness & Sig. & .311 & .011 & .346 & .420 & .174 & .084 \\
& $\mathrm{~B}$ & .003 & .050 & -.065 & -.016 & .111 & -.098 \\
Observing & Sig. & .947 & .626 & .468 & .910 & .276 & .265 \\
& $\mathrm{~B}$ & .279 & .246 & .182 & .314 & .115 & .183 \\
Describing & Sig. & .003 & .020 & .044 & .029 & .263 & .041 \\
& $\mathrm{~B}$ & .134 & .000 & .262 & .024 & -.027 & .080 \\
Non-React & Sig. & .187 & .997 & .009 & .877 & .810 & .417 \\
& $\mathrm{~B}$ & -.06 & -.120 & .055 & .167 & -.407 & -.022 \\
Non-Judge & Sig. & .656 & .433 & .674 & .432 & .007 & .863 \\
$\mathrm{R}^{2}$ & & .156 & .137 & .397 & .085 & .089 & .090 \\
$\mathrm{~F}$ & & 4.225 & 3.618 & 4.266 & 2.123 & 2.217 & .261 \\
Sig. & & $.001^{* *}$ & $.004^{*}$ & $.001^{* *}$ & .068 & .057 & .053 \\
\hline
\end{tabular}

Keterangan: $*$ signifikan pada level $.05 ; * *=$ signifikan pada level .001 


\section{DISKUSI}

Pada perhitungan regresi ganda dihasilkan bahwa trait mindfulness berperan secara signifikan dengan tiga dimensi kesejahteraan psikologis pada lansia. Dimensi-dimensi tersebut yaitu dimensi penerimaan pribadi, hubungan positif dengan orang lain, dan otonomi. Tiga dimensi kesejahteraan psikologis lainnya yang tidak memiliki nilai signifikan yaitu dimensi penguasaan lingkungan, tujuan hidup, dan pertumbuhan pribadi.

Penelitian sebelumnya menunjukkan bahwa trait mindfulness merupakan prediktor yang signifikan terhadap semua dimensi pada kesejahteraan psikologis (Sanoveriana \& Fourianalistyawati, 2017). Trait mindfulness dapat membantu seseorang dalam memaknai suatu pengalaman dengan kata-kata. Hal ini dapat membantu dalam meningkatkan kesejahteraan psikologis seseorang secara keseluruhan dengan mengurangi perasaan negatif yang dialami oleh orang tersebut. Trait mindfulness juga dapat membantu seseorang dalam meregulasi emosi dan lebih fokus terhadap apa yang sedang dilakukan saat ini, sehingga dapat meningkatkan kesejahteraan psikologis seseorang (Baer dkk., 2008).

Dalam penelitian ini, trait mindfulness berperan signifikan terhadap dimensi penerimaan diri dalam kesejahteraan psikologis. Hal ini berarti kesadaran lansia akan potensi serta keterbatasan yang dimilikinya akan mendorong munculnya penerimaan diri secara utuh. Penerimaan diri adalah kemampuan individu dalam mengakui dan menerima berbagai aspek dalam diri, serta merasa positif terhadap kehidupan yang dijalani saat ini (Ryff, 1989). Bagi lansia, setiap hari adalah kemungkinan hari yang terakhir untuk mereka hidup, sehingga mereka akan memanfaatkan sisa waktu untuk menjadi dan mencintai diri sendiri serta menjalin hubungan baik dengan orang lain (Papalia, Olds, \& Feldman, 2013). Maka dari itu, terdapat hubungan positif antara penerimaan diri dan harapan hidup lansia (Hariyadi, 2014). Lansia yang memiliki penerimaan diri yang baik akan memiliki harapan hidup yang tinggi.

Trait mindfulness juga berperan signifikan terhadap dimensi hubungan positif dengan orang lain dalam kesejahteraan psikologis. Melalui kesadaran yang penuh akan dirinya, tercipta hubungan yang positif dan konstruktif dengan orang lain. Hubungan positif dengan orang lain adalah membina hubungan yang hangat dan saling percaya, dicirikan dengan adanya kemampuan untuk mencintai dan menjalin persahabatan yang mendalam (Ryff, 1989). Mayoritas lansia memiliki teman dekat. Adanya interaksi intensif dengan teman dekat akan membuat lansia cenderung lebih sehat dan bahagia. Bagi usia lanjut, selektif dalam memilih pertemanan dirasa sangat penting dengan kondisi fisik yang semakin menurun (Papalia dkk., 2013). 
Dimensi kesejahteraan psikologis lainnya yang dipengaruhi oleh trait mindfulness adalah dimensi otonomi. Melalui kesadaran yang realistik di dalam diri, termasuk mengenai kondisi fisiknya, lansia akan semakin mampu mengembangkan otonomi dalam dirinya. Lansia yang masih mampu beraktivitas secara fisik akan cenderung ingin melakukan segala aktivitasnya sendiri. Bahkan lansia cenderung mencari kegiatan agar tidak merasa bosan, serta ingin menghabiskan waktunya dengan melakukan hal yang bermakna.

Dalam penelitian ini, terdapat beberapa dimensi dari kesejahteraan psikologis yang tidak dipengaruhi oleh trait mindfulness. Hal ini dapat terjadi karena perbedaan budaya di Indonesia (Sanoveriana \& Fourianalistyawati, 2017). Trait mindfulness melatih seseorang untuk memiliki sikap non-reaktif terhadap pengalaman. Hal ini dapat membantu meningkatkan kesejahteraan psikologis seseorang. Namun, Indonesia memiliki budaya kolektivistik sehingga seseorang dituntut untuk mengevaluasi dirinya agar dapat menyesuaikan diri dengan baik di dalam lingkungan. Hal ini bertentangan dengan sikap non-reaktif terhadap pengalaman pada trait mindfulness. Kemudian, trait mindfulness juga membuat seseorang untuk sadar dan fokus pada stimulus internal maupun eksternal yang dialaminya, seperti sensasi, pikiran, dan emosi yang sedang dialami. Menurut Royuela-Colomer dan Calvete (2016), hal ini dapat mendorong seseorang untuk lebih rentan terhadap depresi. Namun, ini tidak terjadi pada individu yang rutin melakukan meditasi berbasis trait mindfulness (Neale-Lorello \& Haaga, 2015).

Penguasaan lingkungan adalah salah satu dimensi pada kesejahteraan psikologis yang tidak dipengaruhi oleh trait mindfulness. Penguasaan lingkungan adalah keadaan ketika seseorang dapat menguasai lingkungan, mampu melihat peluang-peluang yang ada, dan akan berdampak positif bagi kehidupan orang tersebut (Ryff, dalam Papalia, Olds, \& Feldman, 2004). Pada lansia, hal ini sudah sulit dilakukan karena adanya keterbatasan fisik dan perubahan keadaan sosial. Menurut Simanjuntak (2012), perkembangan kondisi lingkungan mengakibatkan lansia sulit beradaptasi dengan suasana sekitar karena ingatan yang semakin melemah dan adanya keterbatasan kondisi fisik dalam beraktivitas. Hal ini juga sesuai dengan teori pelepasan (disengangement theory) yang mengasumsikan bahwa penuaan biasanya membawa penurunan perlahan dalam keterlibatan sosial dan menaruh perhatian yang lebih besar terhadap diri sendiri (Cuming \& Hendry, dalam Papalia dkk., 2013).

Dimensi psychological well-being berikutnya yang tidak dipengaruhi oleh trait mindfulness yaitu dimensi tujuan hidup. Individu yang memiliki tujuan hidup adalah yang memiliki arah dalam hidup, merasa bahwa kehidupan di masa lalu dan masa sekarang memiliki makna, serta memegang keyakinan yang memberikan tujuan dalam hidup. Primardi dan Hadjam (2010) mengungkapkan bahwa lansia di panti memiliki dukungan keluarga yang sangat rendah, sehingga tujuan hidup juga 
menjadi rendah. Sementara, dukungan dari keluarga memiliki peran yang sangat penting terhadap seseorang dalam menjalani kehidupannya. Keadaan ini biasanya disebabkan oleh pensiun yang akan membuat lansia merasa kehilangan status, teman dan aktivitas di lingkungan, terlebih lagi ketika teman sebaya sudah lebih dahulu meninggalkannya (Indriana dkk, 2011).

Dimensi pertumbuhan pribadi juga merupakan dimensi yang tidak ditemukan berkontribusi signifikan dari trait mindfulness. Beberapa lansia yang tinggal di panti saat pengambilan data juga menyatakan bahwa mereka menyesali kehidupannya. Mereka merasa belum menjadi orang yang berkembang sampai dengan hari tua. Lansia yang sudah ditinggalkan pasangan, tidak memiliki pendidikan yang tinggi, dan belum memiliki anak biasanya memiliki nilai pertumbuhan pribadi rendah. Hal ini sesuai dengan penelitian Maramis (2016) mengenai kebermaknaan hidup lansia, yang menunjukkan bahwa pendidikan yang rendah atau pengalaman yang tidak menyenangkan membuat lansia menyesali masa lalunya, sehingga merasa tidak puas dengan kehidupan yang telah dijalani.

Pada penelitian ini, peneliti belum dapat menjelaskan faktor lain, selain trait mindfulness, yang berkontribusi terhadap kesejahteraan psikologis pada lansia. Namun berdasarkan studi literatur yang telah ditemukan, faktor-faktor yang memengaruhi kesejahteraan psikologis adalah usia, gender, tingkat pendidikan, dan budaya. Beberapa bentuk aktivitas tertentu, seperti aktivitas mengingat kembali masa lalu yang dapat membantu mengkonstruksikan kesadaran yang realistis bagi lansia (Himawan, Risnawaty, \& Wirawan, 2014) juga dapat meningkatkan kesejahteraan psikologis lansia.

Salah satu dimensi trait mindfulness yang tidak berperan signifikan terhadap semua dimensi kesejahteraan psikologis pada lansia, yaitu dimensi observing. Hasil ini bertolak belakang dengan hasil penelitian sebelumnya yang menyatakan bahwa observing adalah salah satu aspek yang paling berperan dalam kesejahteraan psikologis individu (Baer dkk, 2008). Hasil penelitian ini mungkin disebabkan oleh adanya pengaruh usia, karena usia merupakan salah satu faktor yang memengaruhi kesejahteraan psikologis. Observing adalah kemampuan memerhatikan pengalaman internal dan eksternal seperti sensasi, kognisi, emosi, suara, aroma dan pengamatan. Pada lansia, kemampuan observing mereka sudah mulai melemah. Kemampuan sensasi pada tubuh dan kognisi sudah semakin menurun (Staudinger \& Bluck, 2001). Hal ini diasumsikan dapat menjelaskan mengapa dimensi observing tidak berperan pada kesejahteraan psikologis pada lansia.

Selama proses penelitian, peneliti menyadari masih terdapat beberapa keterbatasan pada penelitian ini. Kekurangan tersebut seperti tingkat pendidikan lansia yang tidak dikontrol, sehingga lansia yang memiliki tingkat pendidikan di bawah SMP cenderung sulit memahami dan menjawab kuesioner yang diberikan. Selanjutnya, total butir dari alat ukur yang digunakan sebanyak 81 butir. 
Jumlah butir yang banyak membuat lansia mudah lelah dan tidak konsentrasi dalam menjawab pertanyaan berikutnya.

\section{SIMPULAN DAN SARAN}

\section{Simpulan}

Dari hasil penelitian ini, dapat disimpulkan bahwa dimensi trait mindfulness memiliki peran yang signifikan terhadap dimensi penerimaan diri, hubungan positif dan otonomi dari kesejahteraan psikologis.

\section{Saran Teoretis}

Penelitian serupa yang melibatkan lansia hendaknya menggunakan instrumen yang lebih relevan dengan kondisi lansia, seperti menggunakan wawancara atau observasi. Jika hendak menggunakan kuesioner, maka jumlah butir pertanyaan perlu dibatasi atau dapat dilakukan dalam lebih dari satu pertemuan, sehingga tidak membuat lansia merasa kelelahan.

\section{Saran Praktis}

Upaya meningkatkan kesejahteraan psikologis pada lansia dapat dimulai dengan memberikan penyuluhan mengenai manfaat mindfulness kepada lansia. Penyuluhan mengenai pentingnya dukungan sosial keluarga terhadap lansia juga perlu untuk dilakukan. Hal ini dikarenakan lansia juga membutuhkan dukungan dari lingkungan untuk menjadi sejahtera.

\section{REFERENSI}

Ambardini, R. L. (2009). Aktivitas Fisik pada Lajut Usia. Yogyakarta: Universitas Negeri Yogyakarta.

Baer, R. A., Smith, G. T., Hopkins, J., Krietemeyer, J., \& Toney, L. (2006). Using self-report assessment methods to explore facets of mindfulness. Assessment, 13(1), 27-45.

Baer, R. A., Smith, G. T., Lykins, E., Button, D., Krietemeyer, J., Sauer, S., Walsh, E., Duggan, D., \& Williams, J. M. G. (2008). Construct validity of the five facet mindfulness questionnaire in meditating and nonmeditating Samples. Assessment, 15(3), 329-342.

Desiningrum, D. R. (2014). Kesejahteraan psikologis lansia janda/duda ditinjau dari persepsi terhadap dukungan sosial dan gender. Jurnal Psikologi Undip, 13(2), 102-106. 
Fourianalistyawati, E., Listiyandini, R. A., \& Fitriana, T. S. (2016). Hubungan trait mindfulness dengan kualitas hidup orang dewasa di Jabodetabek. Forum Ilmiah Psikologi Indonesia (FIPI), 1, 31-43.

Gumelar, R. (2014). Peningkatan kesejahteraan sosial lansia (studi kasus program pelayanan kesejahteraan lansia di UPT Panti Wredha Budhi Dharma kota Yogyakarta, Ponggalan UH. 7/003 RT $14 R W V$, Yogyakarta) (Skripsi tidak dipublikasikan). UIN Sunan Kalijaga, Indonesia.

Hawari. (2007). Sejahtera di usia senja dimensi psikoreligi pada lanjut usia (lansia). Jakarta: Balai Penerbit FKUI.

Hariyadi, Y. (2014). Hubungan antara penerimaan diri lansia dengan angka harapan hidup di kelurahan wates kota Mojokerto. Jurnal Medica Majapahit, 6(2), 78-95.

Himawan, K. K., Risnawaty, W., \& Wirawan, H. (2014). Effect of reminiscence group therapy on depressive symptoms of the nursing home elderly residence in Tangerang. The Guidance Journal, 42, 1-22.

Hurlock, E. (2004). Psikologi perkembangan. Jakarta: Erlangga.

Hurlock, E. (2008). Psikologi perkembangan: Suatu pendekatan sepanjang rentang kehidupan. Jakarta: Erlangga

Indriana, Y., Desiningrum, D. R., \& Kristiana, I. F. (2011). Religiositas, keberadaan pasangan dan kesejahteraan sosial (social well-being) pada lansia binaan PMI cabang Semarang. Jurnal Psikologi Universitas Diponegoro, 10(2), 184-193.

Jasmarizal, Sastra, L., \& Yunita, D. (2011). Pengaruh terapi musik klasik (Mozart) terhadap penurunan tekanan darah sistolik pada lansia dengan hipertensi di wilayah kerja puskesmas air dingin kecamatan Koto Tangah Padang tahun 2011. Jurnal Mercubaktijaya, 3(2), 3-9.

Kabat-Zinn, J. (2003). Mindfulness-based interventions is context: Past, present, future. Clinical Psychology: Science and Practise, 10, 144-156.

Khotimah. (2011). Pengaruh rendam air hangat dalam meningkatkan kuantitas tidur lansia. Skripsi. PSIK. Universitas Pesantren Tinggi Darul Ulum, Jombang.

Kinasih., \& Sukma, A. (2010). Pelatihan mindfulness untuk meningkatkan kesejahteraan psikologis pada remaja difabel fisik (Tesis Magister tidak dipublikasikan). Universitas Gadjah Mada, Indonesia.

Listiyandini, R. A., \& Brebahama, A. (2015). Psychological well-being of young adulthood with visual impairment in Jakarta. Disajikan dalam Regional Conference of the ICEVI (International Council for Education of People with Visual Impairment) East Asia Region.

Lu, L. (2010). Leisure and depression in midlife: A Taiwanese national survey of middle-aged 
adult. Journal of Health Psychology. 16(1), 137-147.

Maramis, R. L. (2016). Kebermaknaan hidup dan kecemasan dalam menghadapi kematian pada lansia di panti Werdha Samarinda. eJournal Psikologi, 4(3). Diunduh dari http://ejournal.psikologi.fisip-unmul.ac.id/site/?p=943

Mustari, A. S., Rachmawati, Y., \& Nugroho, S. W. (2015). Statistik Penduduk Lanjut Usia 2014. Jakarta: Badan Pusat Statistik.

Neale-Lorello, D., \& Haaga, D. A. F. (2015). The "observing" facet of mindfulness moderates stress/symptom relations only among meditators. Mindfulness, 6(6), 1286-1291.

Nurhidayah, S., \& Agustini, R. (2012). Kebahagiaan lansia ditinjau dari dukungan sosial dan spiritualitas. Jurnal Soul, 5(2), 16-32.

Papalia, D. E., Olds, S. W., \& Feldman, R. D. (2004). Human Development. Boston, MA: McGrawHill.

Papalia, D. E., Olds, S. W., \& Feldman, R. D. (2013). Human Development (Perkembangan manusia edisi 10 buku 2). Jakarta: Salemba Humanika.

Pratiwi, D. E. (2013). Pengaruh senam lansia terhadap tingkat stress pada lansia. Skripsi. Poltekkes, Surakarta.

Primardi, A., \& Hadjam, M. N. R. (2010). Optimisme, harapan, dukungan sosial keluarga, dan kualitas hidup orang dengan Epilepsi. Jurnal Psikologi, 3(2), 123-133.

Royuela-Colomer, E., \& Calvete, E. (2016). Mindfulness facets and depression in adolescents: Rumination as a mediator. Mindfulness, 7(5), 1092-1102.

Ryff, C. D. (1989). Happiness is everything, or is it? Explorations on the meaning of psychological well-being. Journal of Personality and Social Psychology, 57, 1069-1081.

Ryff, C. D., \& Keyes, C. L. M. (1995). The structure of psychological well-being revisited. Journal of Personality and Social Psychology, 69(4), 719-727.

Sanoveriana, A. S. N., \& Fourianalistyawati, E. (2017). Work-family balance, trait mindfulness and psychological well-being in middle-aged working parents. UI Proceedings on Social Science and Humanities, 1, 1-8.

Simanjuntak, P. A. (2012). Desain alat bantu mobilitas pengguna lanjut usia untuk beraktifitas di tempat umum. Jurnal Bidang Senirupa dan Desain ITB, 1(1), 1-7.

Smith, A. (2004). Clinical uses of mindfulness training for older people. Behavioural and Cognitive Psychotherapy, 32(4), 423-430.

Staudinger, U. M., \& Bluck, S. (2001). A view on midlife development from life-span theory. Dalam M. E. Lachman (Ed.), Handbook of Midlife Development (pp. 3-39). New York, NY: John Wiley \& Sons. 
Syukra, A. (2012). Hubungan antara religiusitas dengan kejadian depresi pada lansia di Panti Sosial Tresna Werdha (Pstw) Sabai Nan Aluih Sicincin Kabupaten Padang Pariaman (Skripsi tidak dipublikasikan). Universitas Andalas, Indonesia.

Teasdale, J. D., Moore, R. G., Hayhurst, H., Pope, M., Williams, S., \& Segal, Z. V. (2002). Metacognitive awareness and prevention of relapse in depression: Empirical evidence. Journal of Consulting and Clinical Psychology, 70, 278-287.

Triratnasari, W. (2009). Perbedaan tingkat kecemasan menghadapi pensiun antara pegawai negeri sipil yang tidak mempunyai pekerjaan sampingan dan mempunyai pekerjaan sampingan di Badan Kepegawaian Daerah Kota Ponorogo. Skripsi. Fakultas Psikologi UIN Maulana Malik Ibrahim, Malang.

Zulfiana, U. (2014). Meningkatkan kebahagiaan lansia di Panti Wreda melalui psikoterapi positif dalam kelompok. Jurnal Sains dan Praktik Psikologi, 2(3), 256-267. 